PNL-10257

UC-606

\title{
Vapor Space Characterization of Waste Tank 241-BY-107: Results from In Situ Sample Collected on 3/25/94
}
A. K. Sharma
R. B. Lucke
T. W. Clauss
B. D. McVeety, Ph.D.
J. S. Fruchter, Ph.D.
S. C. Goheen, Ph.D.

June 1995

Prepared for

Westinghouse Hanford Company under a Related Services Agreement with the U.S. Department of Energy Contract DE-AC06-76RLO 1830

Pacific Northwest Laboratory

Richland, Washington 99352 



\section{DISCLAIMER}

This report was prepared as an account of work sponsored by an agency of the United States Government. Neither the United States Government nor any agency thereof, nor any of their employees, make any warranty, express or implied, or assumes any legal liability or responsibility for the accuracy, completeness, or usefulness of any information, apparatus, product, or process disclosed, or represents that its use would not infringe privately owned rights. Reference herein to any specific commercial product, process, or service by trade name, trademark, manufacturer, or otherwise does not necessarily constitute or imply its endorsement, recommendation, or favoring by the United States Government or any agency thereof. The views and opinions of authors expressed herein do not necessarily state or reflect those of the United States Government or any agency thereof. 


\section{DISCLAIMER}

Portions of this document may be illegible in electronic image products. Images are produced from the best available original document. 


\section{Summary}

This report describes organic results from vapors of the Hanford single-shell waste storage Tank 241-BY-107 (referred to as Tank BY-107). Samples for selected inorganic compounds were obtained but not anlayzed (Section 2.0). Quantitative results were obtained for several organic analytes, but quantities of analytes not listed in U.S. Environmental Protection Agency (EPA) compendium Method TO-14 were estimated (see Summary Table 1). Approximately 80 tentatively identified organic analytes were observed above the detection limit of (ca.) $10 \mathrm{ppbv}$, but standards for most of these were not available at the time of analysis, and their quantitative determination is beyond the scope of this study. The SUMMA ${ }^{\text {TM }}$ canister samples were also analyzed for the 41 organic compounds listed in EPA compendium Method TO-14. Of these, only a few were observed above the 2-ppbv detection limits. These are summarized in Table 3.1. Estimated quantities were determined of tentatively identified compounds (TICs). A summary of these results (Table 3.2) shows quantities of all TICs above the concentration of ca. $10 \mathrm{ppbv}$. This consists of more than 80 organic analytes. The 12 organic analytes with the highest estimated concentrations are shown in Summary Table 1 below. These 12 analytes account for approximately 55\% of the total organic components in Tank BY-107. Detailed descriptions of the results appear in the text.

Summary Table 1. Summary Results of Selected Organic Analytes

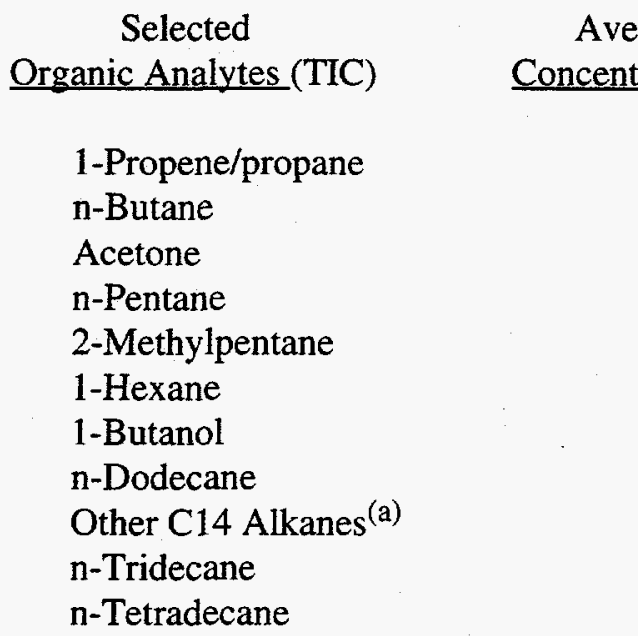

(a) Other structural isomers should be considered. 



\section{Acknowledgments}

The authors gratefully acknowledge the support of other project staff at Pacific Northwest Laboratory who contributed to the successful completion of this sampling and analysis activity. Jeff Edwards served as the PNL single-point-of-contact and coordinated sample handling and communications with Westinghouse Hanford Company. Jeff also supported work in the analytical laboratory. Annalisa Krupsha and Gary Dennis prepared the solid-sorbent sample trains. Georgia Ruebsamen provided word processing support. 



Abbreviatio
chain of custody
U.S. Environmental Protection Agency
gas chromatography/mass spectrometry
high efficiency particulate air
Hewlett Packard
internal standard
normal paraffin hydrocarbon
part per billion by volume
part per million by volume
Pacific Northwest Laboratory
standard temperature and pressure
tentatively identified compound
Westinghouse Hanford Company





\section{Contents}

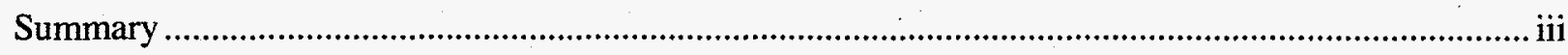

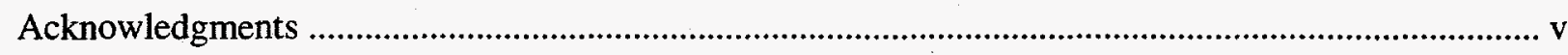

Abbreviations ……............................................................................................................... vii

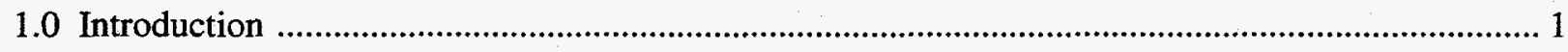

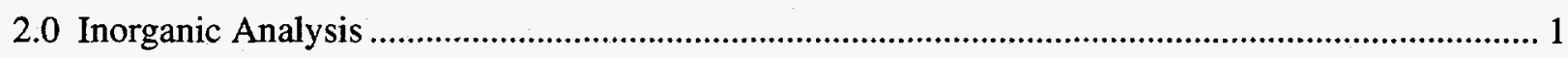

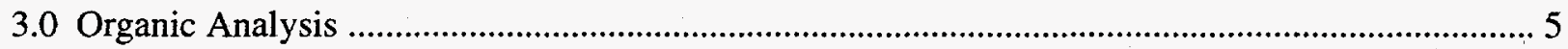

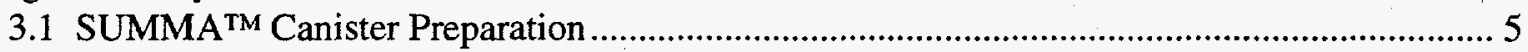

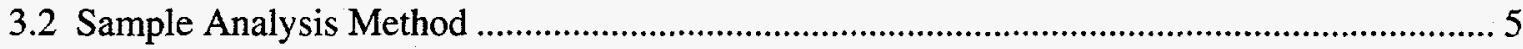

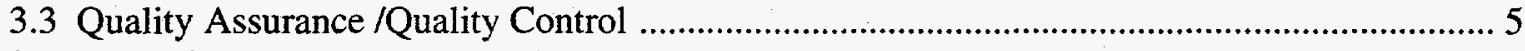

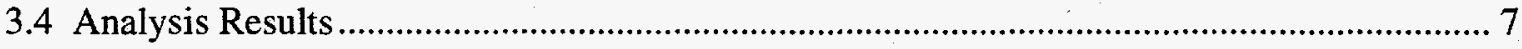

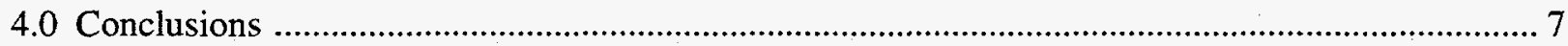

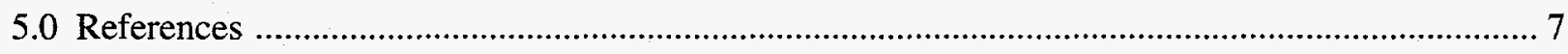

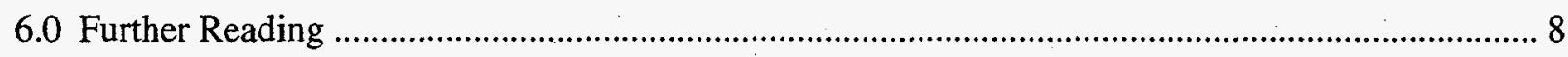

\section{Tables}

3.1 TO-14 Analysis Results for In Situ Sample S4011-SUM.075, Collected from Tank BY-107 in SUMMA ${ }^{\mathrm{TM}}$ Canisters on 3/25/94 ......................................................... 9

3.2 Table of Tentatively Identified Compounds and Estimated Concentrations in Tank BY-107 In Situ SUMMA ${ }^{\text {TM }}$ Canister Sample S4011-SUM-075 Collected on $3 / 25 / 94$

\section{Figures}

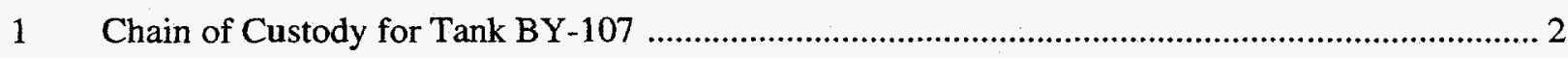

3.1 GC/MS Chromatogram of Hanford Waste Tank BY-107 In Situ SUMMA ${ }^{\text {TM }}$ Canister Vapor Sample S4011-SUM-075 Collected on 3/25/94 


\subsection{Introduction}

This report describes results of the analysis of vapor samples taken from the Hanford waste Tank 241-BY-107 (referred to as Tank BY-107) on March 25, 1994. Preliminary results of the SUMMATM canister analysis for this tank are included in the interim letter report Hanford Waste Tank BY-107 and BY-108 Preliminary Report Draft submitted to Westinghouse Hanford Company (WHC) on 4/22/94 (a). The WHC sample job number was $\$ 4011$.

Sampling devices including sorbent trains (for inorganic analyses) and SUMMA ${ }^{\mathrm{TM}}$ canisters (for organic analysis) were supplied to the WHC sampling staff on March 23, 1994. Samples were taken (by WHC) on March 25 and were returned from the field on March 29. Inorganic (sorbent trains) samples delivered to Pacific Northwest Laboratory (PNL) ${ }^{(b)}$ on chain of custody (COC) 006857 (Figure 1a) included 6 samples. SUMMA ${ }^{\mathrm{TM}}$ samples delivered to PNL on COC 006850 (Figure 1b) included one surrogate and one tank-headspace SUMMA ${ }^{\text {TM }}$ canister sample.

The samples were inspected upon delivery to the 326/23B laboratory and logged into PNL laboratory record book 55408. Sorbent trains were found to contain levels of radioactivity exceeding our standard inorganic laboratory capacity. These samples were subsequently returned to WHC. The canisters were stored in the $326 / 23 \mathrm{~B}$ laboratory at ambient $\left(25^{\circ} \mathrm{C}\right)$ temperature until the time of analysis. Access to the 326/23B laboratory is limited to PNL personnel working on the waste tank safety program. Analyses described in this report were performed at PNL in the 300 area of the Hanford Reservation. Methods used for organic analyses are described in the text of this report. Organic analyses were performed using gas chromatography/mass spectrometry (GC/MS).

\subsection{Inorganic Analysis}

Solid sorbent trains for ammonia, nitrogen dioxide, nitric oxide, hydrogen cyanide, and water were supplied. The traps were inserted into the waste tank and used to sample the tank headspace. Available information from a radiological survey of the samples indicated the presence of external contamination and potential internal contamination; therefore, the samples were not analyzed chemically; gravimetric results indicated a vapor mass concentration of approximately $7 \mathrm{mg} / \mathrm{L}$ (expected to be largely water vapor). To reduce the possibility of contamination in subsequent sample jobs, a wrapped high-efficiency particulate air (HEPA)-filtered inlet manifold has since been designed for use upstream of in situ trains.

(a) Report written by B. D. McVeety, J. S. Fruchter, R. B. Lucke, and S. C. Goheen. Pacific Northwest Laboratory, Richland, Washington.

(b) Pacific Northwest Laboratory is operated for the U.S. Department of Energy by Battelle Memorial Institute under Contract DE-AC06-76RLO 1830. 


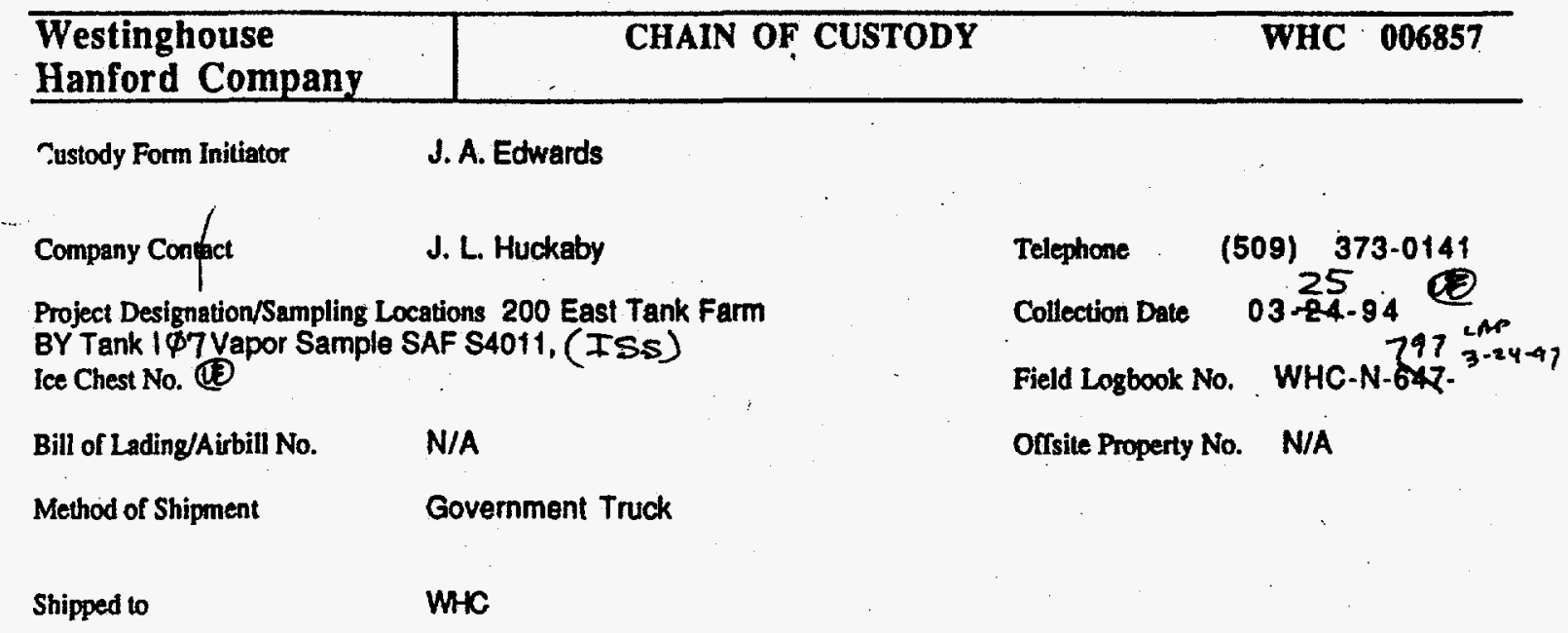

Possible Sample Hazards/Remarks Unknown at time of sampling

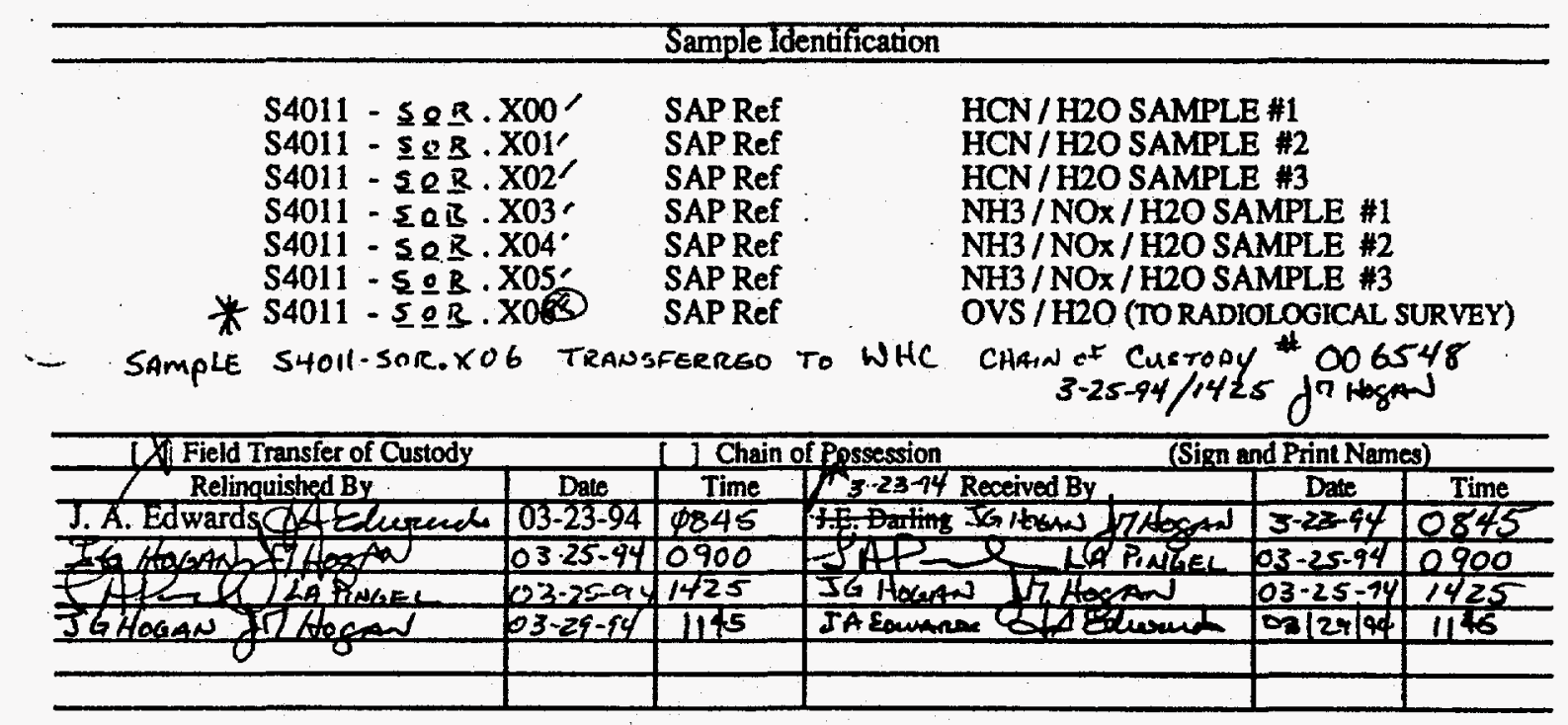

Final Sample Disposition

Disposal Method:

Disposed by:

Date/Time:

Comments

A-6000-407 (12/92) WEF061

Figure 1a. Chain of Custody for Inorganic Samples from Tank BY-107 


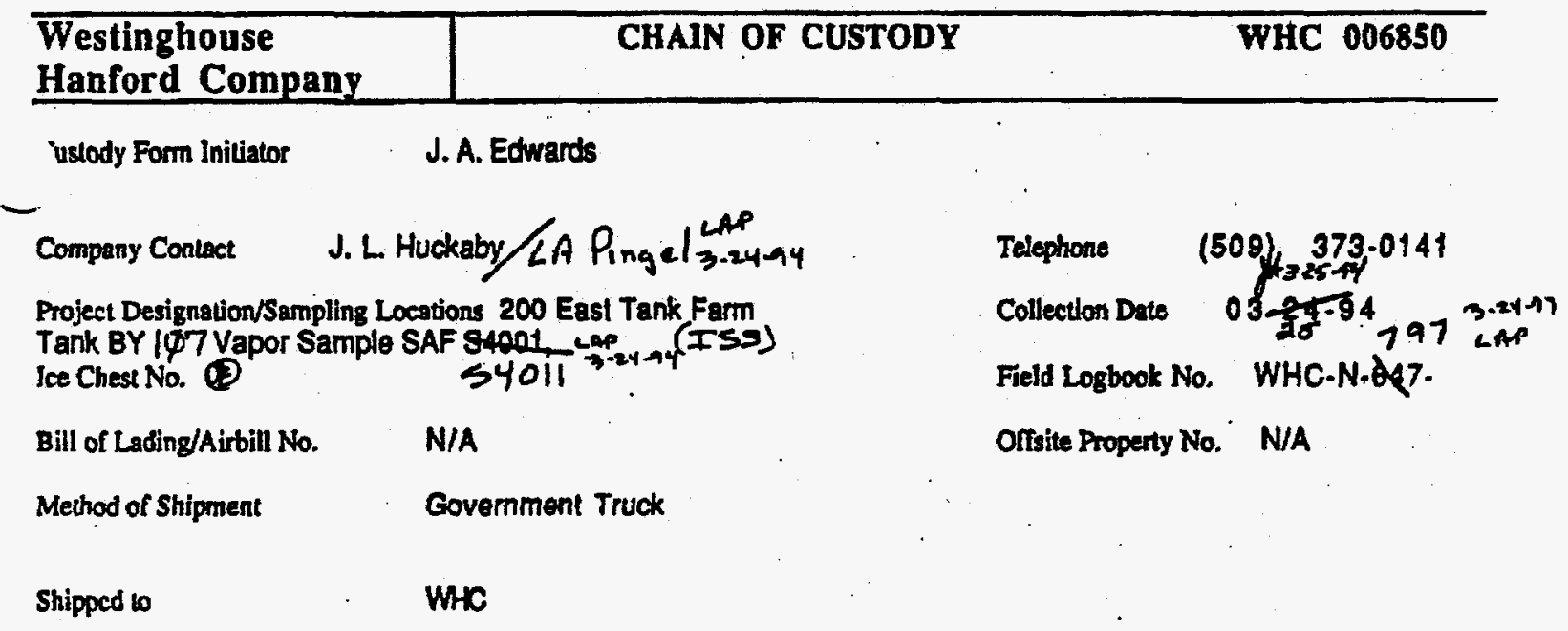

Possible Sample HazardsRemarks Unknown at time of sampling

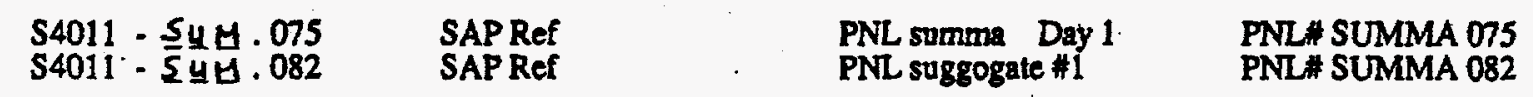

\begin{tabular}{|c|c|c|c|c|c|}
\hline I Field Transfer of Cuslody & & \multicolumn{2}{|c|}{ Chain of Possession } & \multicolumn{2}{|c|}{ (Sjzn and Print Names) } \\
\hline Relinguished By & Dale & Time & W/3-23-44 Received By & Date & Time \\
\hline dwards 5 teduenet & $03-23-94$ & 0845 & FEDaring IG $4 \mathrm{x}$ & $3-23-54$ & $084 / 5$ \\
\hline EAar & $03-25-54$ & 0900 & & $03 \cdot 25-94$ & 082 \\
\hline- & $3-29-24$ & 0900 & 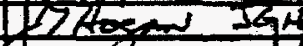 & 329.54 & 0100 \\
\hline$x=1$ Indean & $3-29-94$ & 1150 & It Elumana & $329-14$ & 1150 \\
\hline & & & & & \\
\hline
\end{tabular}

Final Sample Disposition

Disposal Method:

Disposed by:

Date/Time:

Comments

Figure 1b. Chain of Custody for Organic Samples from Tank BY-107 


\subsection{Organic Analysis}

\subsection{SUMMA ${ }^{\mathrm{TM}}$ Canister Preparation}

Before sending SUMMA ${ }^{\mathrm{TM}}$ canisters out to the field for sampling, the canisters are cleaned and verified contaminant free according to PNL Technical Procedure PNL-TVP-02 ${ }^{(a)}$. The cleaning procedure uses an EnTech 3000 cleaning system that controls 1) filling the canisters with purified humid air and 2) evacuating, for several cycles with applied heat, before allowing the canister to evacuate overnight. The canister is filled a final time with purified humid air for analysis by PNL Technical Procedure PNL-TVP-01 ${ }^{(\mathrm{b})}$, which is a modification of U.S. Environmental Protection Agency (EPA) Compendium Method TO-14. If the canister is verified as clean, free of TO-14 contaminants to a level of $5 \mathrm{ppbv}$, the canister is evacuated to $30 \mathrm{in}$. $\mathrm{Hg}$, tagged, and stored for use in the field. Before sending the canisters out to the field for sampling, the canisters are prehumidified with $100 \mu \mathrm{L}$ of distilled water and labeled with a field sampling identification. Canisters not used after 30 days of storage are recleaned and validated before use.

\subsection{Sample Analysis Method}

The SUMMATM canister sample was analyzed according to PNL Technical Procedure PNL-TVP03, Determination of TO-14 Volatile Organic Compounds in Hanford Waste Tank Headspace Samples Using SUMMA ${ }^{\mathrm{TM}}$ Passivated Canister Sampling and Gas Chromatographic-Mass Spectrometry Analysis. The method uses an EnTech cryoconcentration system that is interfaced with a Hewlett Packard (HP) $5971 \mathrm{GC} / \mathrm{MS}$. The EnTech concentrator is used to pull a metered volume of sample air from the SUMMA ${ }^{\mathrm{TM}}$ canister, cryogenically concentrate the air volume, then transfer the volume to the GC/MS for analysis. A 100-mL volume of sample is measured and analyzed from the tank headspace sample. The organic components in the sampled air are separated on an analytical column, J\&W Scientific DB-1 phase , $60-\mathrm{m}$ by $0.32-\mathrm{mm}$ inside diameter with $3-\mu \mathrm{m}$ film thickness. The GC column is programmed for a temperature gradient beginning at $40^{\circ} \mathrm{C}$, holding for $5 \mathrm{~min}$, and ramping at $4^{\circ} \mathrm{C}$ per min to a final temperature of $260^{\circ} \mathrm{C}$, with a 5 -min hold.

\subsection{Quality Assurance/Quality Control}

Before the tank sample was analyzed, a diagnostic check was performed on the GC/MS instrument by running an instrument "quick tune," as described in PNL-TVP-03 ${ }^{\text {(c) }}$. Upon satisfactory completion of the instrument diagnostic check, a blank volume of purified nitrogen was analyzed to check the cleanliness of the system. The instrument was then calibrated over 6 data points ranging from $2 \mathrm{ppbv}$ to $100 \mathrm{ppbv}$, using a standard gas mixture containing 40 volatile organic compounds listed in U.S. Environmental Protection Agency (EPA) compendium Method TO-14. A gas mixture containing bromochloromethane, 1,4-difluorobenzene, and chlorobenzene- $d_{5}$ was used as an internal standard (IS) for all blank, calibration standard, and sample analyses. The calibration curve was generated by

(a) Pacific Northwest Laboratory. 1994. Cleaning SUMMATM Canisters and the Validation of the Cleaning Process, PNL-TVP-02 (Rev. 0), PNL Technical Procedure, Richland, Washington.

(b) Pacific Northwest Laboratory. 1994. Determination of TO-14 Volatile Organic Compounds in Ambient Air Using SUMMATM Passivated Canister Sampling and Gas Chromatographic-Mass Spectrometric Analysis, PNL-TVP-01 (Rev. 0). PNL Technical Procedure, Richland, Washington.

(c) Pacific Northwest Laboratory. 1994. Determination of TO-14 Volatile Organic Compounds in Hanford Waste Tank Headspace Samples Using SUMMA ${ }^{\mathrm{TM}}$ Passivated Canister Sampling and Gas ChromatographicMass Spectrometry Analysis, PNL-TVP-03 (Rev. 0), PNL Technical Procedure, Richland, Washington. 
calculating the relative response ratios of the IS to calibration standard responses and plotting the ratios against the ratio of the calibration-standard concentration (in $\mathrm{ppb}$ ) to the IS concentration. A least-squares linear-regression routine was applied to the data set to generate the best-fit line for each compound. The equation for that line was then used to determine the concentration of the specific compounds in the tank samples.

3.2.1 Quantitation of TO-14 Results. The quantitative analysis results for the TO-14 volatile organic compounds were calculated directly from the calibration curve generated using the IS method described above and in PNL-TVP-03. The conversion from ppmv to $\mathrm{mg} / \mathrm{m}^{3}$ assumes standard temperature and pressure (STP) conditions of 760 torr and $273^{\circ} \mathrm{K}$ and was calculated directly from the following equation:

$$
\mathrm{mg} / \mathrm{m}^{3}=\frac{\text { ppmv } \times \text { molecular weight of compound }}{22.4 \mathrm{~L} / \mathrm{mol}}
$$

3.2.2 Identification and Quantitation of Tentatively Identified Compounds. The TICs are determined by performing a mass-spectral library search on each integrated peak using the EPA/NIST/ WILEY Library, which is a part of the HP 5971 instrument operating system. Chromatographic peaks with an area count greater than, or equal to, one half of the total area count of the chlorobenzene- $\mathrm{d}_{5}$ IS peak at the 20-ppbv calibration level are tentatively identified and quantitatively estimated. This standard was chosen to determine the integration cutoff as it is in the middle of the chromatographic range, and not in a region affected by coelution of other compounds. The quality of the mass-spectral searches was then reviewed by the principal investigators before the identification was assigned to each chromatographic peak.

The concentration of each TIC was estimated using a relative response factor calculated using a corrected total peak area for the IS chlorobenzene- $d_{5}$. Specifically, the total integrated area for the chlorobenzene- $\mathrm{d}_{5}$ peak had to be corrected for coeluting compounds before calculating the response factor. The corrected total peak area for the IS was calculated by multiplying the IS quantitation ion by a correction factor based on the ratio of the total integrated peak area to the quantitation ion as measured in blank runs. The corrected peak area was then used to calculate a response factor using the IS concentration in $\mathrm{mg} / \mathrm{m}^{3}$ :

$$
\text { Response Factor }=\frac{\text { IS conc. }\left(\mathrm{mg} / \mathrm{m}^{3}\right)}{\text { IS peak area }}
$$

The calculated response factor was then multiplied by the TIC peak area to give an estimated concentration for that compound. For butane, the total peak area was multiplied by the response factor for chlorobenzene- $d_{5}$ to give an estimated concentration of $5.05 \mathrm{mg} / \mathrm{m}^{3}$. Internal standards bromochloromethane and difluorobenzene were not used to quantitate the TIC because coeluting compounds appeared to have greatly altered the signal of the quantitation ions for those two ISs. analyte.

The ppbv concentrations are calculated concentrations from $\mathrm{mg} / \mathrm{m}^{3}$ and the molecular weight of the

$$
\text { TIC in ppbv }=\frac{\operatorname{TIC}\left(\mathrm{mg} / \mathrm{m}^{3}\right) \times 22.4 \mathrm{~L} / \mathrm{mol} \times 1000}{T I C \mathrm{~g} \mathrm{~mol} \mathrm{wt}}
$$


The IS level added to all blank, standard, and sample injections was $18.2 \mathrm{ppbv}$ for bromochloromethane, $20.2 \mathrm{ppbv}$ for 1,4-difluorobenzene, and $18.3 \mathrm{ppbv}$ for chlorobenzene- $\mathrm{d}_{5}$. The IS concentrations were converted from ppbv at STP to $\mathrm{mg} / \mathrm{m}^{3}$ using a molecular weight of $129.39(\mathrm{~g} / \mathrm{mol})$ for bromochloromethane, 114.09 for 1,4-difluorobenzene, and 117.6 for chlorobenzene- $\mathrm{d}_{5}$.

\subsection{Analysis Results}

The results from the GC/MS analysis of the tank headspace samples are presented in Tables 3.1 and 3.2. A representative total ion chromatograph showing identity of major constituents is given in Figure 3.1.

Table 3.1 lists the quantitative results for compounds listed in Method TO-14. The levels of TO-14 analytes observed in the samples collected from Tank BY-107 were similar to those seen in Tank BY108. The most predominant TO-14 species seen in this sample were freon-11 ( $255 \mathrm{ppbv}$ ) and toluene (202 ppbv). The other TO-14 compounds seen were at 25 ppbv or less.

Table 3.2 lists the semi-quantitative results for the TICs. The predominant species observed in this sample were coeluting peaks 1-propene / propane, butane, acetone, pentane, 2-methylpentane, hexane, and butanol. The acetone concentration reported for this sample may be underestimated because the signal for this compound overloaded the GC/MS detector. As in previous tanks, normal paraffin hydrocarbons (NPH) were present in the sample, but did not constitute the major portion of organic components seen. However, it should be noted that because the SUMMA ${ }^{\mathrm{TM}}$ canisters were not heated at the time of analysis, the NPH concentrations listed after the retention time of decane may not be a true accounting of all the NPH in the sample. Similarly, polar compounds that may adhere to the inside surface of the canister may also be under represented in this analysis. The total concentration of the TIC compounds was approximately $68.3 \mathrm{mg} / \mathrm{m}^{3}$.

\subsection{Conclusions}

The concentrations of selected organic compounds were determined from samples of the tank headspace of Hanford Tank BY-107. Samples for selected inorganic compounds were obtained but not analyzed (Section 2.0). Twelve of the TO-14 analytes and 86 TICs were observed above the detection limit of ca. $10 \mathrm{ppb}$. The sum of these analytes was approximately $70 \mathrm{mg} / \mathrm{m}^{3}$ or about $20 \%$ the concentration of organic compounds in Tank C-103 (Ligotke et al. 1994) (Huckaby and Story 1994).

\subsection{References}

Huckaby, J. L. and M. S. Story. 1994. Vapor Characterization of Tank 241-C-103, WHC-EP-0780, Westinghouse Hanford Company, Richland, Washington.

Ligotke, M. W., T. R. Clauss, J. S. Fruchter, R. B. Lucke, D. W. Dennis, G. M. Mong, R. E. Hoheimer, M. McCulloch, M. T. Dana, and S. C. Goheen. 1994. Aerosol and Vapor Characterization of Tank 241C-103: Data Report for In Situ OVS Samples Obtained 12/2/93, PNL-9368, Pacific Northwest Laboratory, Richland, Washington. 


\subsection{Further Reading}

McVeety, B., Lucke, R., Fruchter, J., Goheen, S., Hanford Waste Tank BY-107 and BY-108, Preliminary Letter Report DRAFT, 4/94, Pacific Northwest Laboratory, Richland, Washington.

Pacific Northwest Laboratory. Analytical Laboratory Operations Procedure Compendium. Procedures PNL-ALO-212, -226, -271. PNL-MA-599, Richland, Washington.

Pacific Northwest Laboratory. Quality Assurance Manual, Part 2: Good Practices Standard. PNL-MA70, Part 2, Richland, Washington.

Pacific Northwest Laboratory. Quality Assurance Plan for Activities Conducted by the Analytical Chemistry Laboratory (ACL). MCS-033, Analytical Chemistry Laboratory, Richland, Washington.

Pacific Northwest Laboratory. 1994. Determination of TO-14 Volatile Organic Compounds in Ambient Air Using SUMMA ${ }^{\mathrm{TM}}$ Passivated Canister Sampling and Gas Chromatographic-Mass Spectrometry Analysis, PNL Technical Procedure, PNL-TVP-01 (Rev. 0), Richland, Washington.

Pacific Northwest Laboratory. 1994. Cleaning SUMMA ${ }^{\mathrm{TM}}$ Canisters and the Validation of the Cleaning Process, PNL Technical Procedure, PNL-TVP-02 (Rev. 0), Richland, Washington.

Pacific Northwest Laboratory. 1994, Sample Shipping and Receiving Procedure - DRAFT for PNL Waste Tank Samples, PNL Technical Procedure, PNL-TVP-07 (Rev. 0), Richland, Washington. 
Table 3.1 TO-14 Analysis Results for In Situ Sample S4011-SUM.075 ${ }^{(\mathrm{a})}$, Collected from Tank BY-107 in SUMMA ${ }^{\text {TM }}$ Canisters on 3/25/94

\section{TO-14 Analyte}

Dichlorodifluoromethane (FREON-12) Methyl chloride (chloromethane)

1,2-Dichloro-1,1,2,2,-tetrafluoroethane (FREON-114)

Chloroethene (vinyl chloride)

Methyl bromide (bromomethane)

Ethyl chloride

Trichlorofluoromethane (FREON-11)

1,1-Dichloroethene (1,1-dichloroethylene)

Dichloromethane (methylene chloride)

1,1,2-Trichloro-1,2,2-trifluoroethane (FREON-113)

1,1-Dichloroethane

Cis-1,2-dichloroethene (cis-1,2-dichloroethylene)

Trichloromethane (chloroform)

1,2-dichloroethane

1,1,1-Trichloroethane

Benzene

Carbon tetrachloride

Trichloroethylene

Cis 1,3-dichloropropene

Trans 1,3-dichloropropene

1,1,2-Trichloroethane

Methyl benzene (toluene)

1,2-Dibromoethane

Tetrachloroethene (tetrachloroethylene)

Chlorobenzene

Ethylbenzene

$\mathrm{P} / \mathrm{m}$-xylene (1,3-dimethylbenzene)

Styrene

1,1,2,2-Tetrachloroethane

o-Xylene (1,2-dimethylbenzene)

1,3,5-Trimethylbenzene

1,2,4-Trimethylbenzene

Chloromethylbenzene, alpha (benzyl chloride)

m-Dichlorobenzene (1,3-dichlorobenzene)

p-Dichlorobenzene (1,4-dichlorobenzene)

1,2,4-Trichlorobenzene

Hexachloro-1,3-butadiene
1,2-Cichloropropane

o-Dichlorobenzene (1,2-dichlorobenzene)

\author{
PNL $075^{(b)}$

(ppbv) $\left(\mathrm{mg} / \mathrm{m}^{3}\right)^{(\mathrm{c})}$

$\begin{array}{ll}2.44 & 0.01 \\ 23.01 & 0.05 \\ <2 & <.02 \\ <2 & <.006 \\ <2 & <.009 \\ 2.95 & 0.01 \\ 254.68 & 1.56 \\ <2 & <.009 \\ 1.83 & 0.01 \\ <2 & <.02 \\ <2 & <.009 \\ <2 & <.009 \\ <2 & <.01 \\ <2 & <.009 \\ <2 & <.01 \\ 23.55 & 0.09 \\ <2 & <.01 \\ <2 & <.01 \\ <2 & <.01 \\ <2 & <.01 \\ <2 & <.01 \\ <2 & <.01 \\ 202.7 & 0.83 \\ <2 & <.02 \\ <2 & <.01 \\ <2 & <.01 \\ <2.68 & 0.03 \\ 6.23 & 0.03 \\ <2 & <.01 \\ 1.27 & 0.01 \\ 5.45 & 0.03 \\ <2 & <.01 \\ <2 & <.01 \\ <2 & <.01 \\ <2 & <.01 \\ <2 & <.01 \\ <2 & <.01 \\ <2 & <.02 \\ <2 & 0.03 \\ 2.21 & \end{array}$

(a) WHC ID number.

(b) PNL SUMMA ${ }^{\mathrm{TM}}$ canister number.

(c) Calculated from ppbv using molecular weight of compound, $760 \mathrm{~mm}$ torr, and $0^{\circ} \mathrm{C}$. 
Table 3.2 Table of Tentatively Identified Compounds and Estimated Concentrations in Tank BY-107 In Situ SUMMA ${ }^{\text {TM }}$ Canister Sample S4011-SUM-075(a) Collected on $3 / 25 / 94$

\begin{tabular}{|c|c|c|}
\hline \multirow[b]{2}{*}{$\begin{array}{l}\text { Tentatively Identified } \\
\text { Compound }^{\text {(c }}\end{array}$} & \multicolumn{2}{|c|}{$\underline{\text { PNL }}$ 075 $^{(\mathrm{b})}$} \\
\hline & $\begin{array}{l}\text { Retention } \\
\text { Time }\end{array}$ & $\frac{\text { Concentration }}{\left(\mathrm{mg} / \mathrm{m}^{3}\right)^{(\mathrm{d})}}$ \\
\hline Carbon dioxide & 5.79 & 0.19 \\
\hline Carbon dioxide & 6.11 & 0.92 \\
\hline 1-Propene & 6.66 & 3.85 \\
\hline Propane (coeluent) & & \\
\hline Cyclopropane & 7.27 & 0.34 \\
\hline 2-Methyl propane & 7.53 & 0.94 \\
\hline C4 Alkene (e) & 8.01 & 1.24 \\
\hline Butane & 8.20 & 5.05 \\
\hline Unknown & 8.53 & 0.11 \\
\hline C4 Alkene ${ }^{(\mathrm{e})}$ & 8.74 & 0.66 \\
\hline Ethanol & 9.53 & 0.11 \\
\hline 2-Pentene & 9.73 & 0.20 \\
\hline C5 Alkene & 10.02 & 0.14 \\
\hline Acetone & 10.29 & 5.37 \\
\hline C5 Alkene $\mathrm{e}^{(\mathrm{e})}$ & 10.82 & 0.82 \\
\hline Pentane & 11.24 & 4.97 \\
\hline 1-Pentene & 12.03 & 0.20 \\
\hline Dimethyl butane & 12.77 & 0.08 \\
\hline 1-Propanol & 13.30 & 0.07 \\
\hline 4-Methyl-1-pentene & 13.69 & 0.44 \\
\hline 2-Methylpentane & 14.29 & 3.49 \\
\hline 2-Butanone & 14.71 & 0.79 \\
\hline 3-Methyl pentane & 15.02 & 0.61 \\
\hline 1-Hexene & 15.25 & 0.52 \\
\hline Bromochloromethane (IS) & 15.82 & \\
\hline Hexane (coeluent) & & 2.47 \\
\hline Tetrahydrofuran & 16.75 & 0.24 \\
\hline Methylcyclopentane & 17.43 & 0.44 \\
\hline Butanol & 18.32 & 2.89 \\
\hline 1,4-Difluorobenzene (IS) & 19.35 & \\
\hline 2-Pentanone (coeluent) & & 1.17 \\
\hline 3-Methylhexane & 19.88 & 0.61 \\
\hline Heptane & 21.12 & 1.30 \\
\hline 4-methyl-2-pentanone & 22.32 & 0.10 \\
\hline Methylcyclohexane & 22.68 & 0.21 \\
\hline Toluene & 24.47 & 0.53 \\
\hline C8 Alkane ${ }^{(\mathrm{e})}$ & 24.67 & 0.15 \\
\hline Octane & 26.41 & 0.53 \\
\hline Siloxane & 27.11 & 0.10 \\
\hline C9 Alkane $e^{(e)}$ & 27.98 & 0.16 \\
\hline Chlorobenzene-d5 (IS) & 28.47 & \\
\hline Trimethylcyclohexane & 28.89 & 0.22 \\
\hline 3-Heptanone & 29.84 & 0.34 \\
\hline 2-Heptanone & 29.96 & 0.17 \\
\hline C9 Alkane $\mathrm{e}^{(\mathrm{e})}$ & 30.14 & 0.14 \\
\hline 2-butoxy ethanol & 30.99 & 0.22 \\
\hline Nonane & 31.42 & 0.46 \\
\hline Unknown mixture & 32.40 & 0.10 \\
\hline 2-Octanone & 33.17 & 0.44 \\
\hline
\end{tabular}


Table 3.2 Contd

Tentatively Identified Compound $^{(\mathfrak{c})}$

Trimethylcyclohexane C10 Alkane ${ }^{(e)}$

C9 Ketone ${ }^{(e)}$

Trimethylcyclohexane

C10 Alkene ${ }^{(e)}$

Decane

C10 Alkene ${ }^{(e)}$

C10 Alkane ${ }^{(\mathrm{e})}$

C4 cyclohexane $\mathrm{e}^{(\mathrm{e})}$

C11 Alkane ${ }^{(e)}$

C5 Cyclohexane $e^{(\mathrm{e})}$

Decahydronaphthalene

Unknown

Undecane

C5 Alkene $(\mathrm{e})$

C5 Alkane ${ }^{(e)}$

C5 Alkane ${ }^{(e)}$

Methyldecahydronaphthalene

C5 Cyclohexane ${ }^{(\mathrm{e})}$

C5 Alkane ${ }^{(\mathrm{e})}$

C5 Alkane ${ }^{(e)}$

Methyldecahydronaphthalene

C5 Alkane ${ }^{(\mathrm{e})}$

Unknown

Unknown

Dodecane

C13 Alkane ${ }^{(e)}$

C13 Alkene ${ }^{(\mathrm{e})}$

C2-Decahydronaphthalene ${ }^{(\mathrm{e})}$

C14 Alkane ${ }^{(e)}$

C14 Alkane ${ }^{(\mathrm{e})}$

Tridecane

C14 Alkene ${ }^{(e)}$

C14 Alkane ${ }^{(e)}$

C3-Decahydronaphthalene ${ }^{(\mathrm{e})}$

Unknown

C14 Alkane ${ }^{(e)}$

C14 Alkane ${ }^{(\mathrm{e})}$

C14 Alkane ${ }^{(e)}$

Tetradecane

Unknown

C15 Alkane $e^{(e)}$

Pentadecane

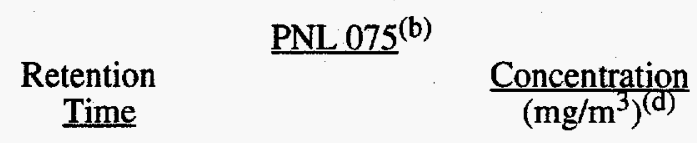

33.42

34.41

34.83

35.04

35.88

36.08

36.69

37.21

37.99

38.11

39.18

39.71

40.22

40.40

40.99

41.22

41.66

41.89

42.11

42.47

42.67

42.87

43.04

43.35

44.18

44.43

45.05

46.49

46.73

46.88

47.30

48.17

48.63

48.93

49.50

50.30

50.50

50.74

51.04

51.67

51.88

53.86

54.94
0.12

0.08

0.10

0.15

0.07

0.37

0.08

0.20

0.06

0.20

0.07

0.11

0.10

0.70

0.16

0.11

0.18

0.09

0.20

0.23

0.21

0.28

0.23

0.15

0.16

2.01

1.46

0.74

0.21

0.33

1.96

2.89

0.37

0.45

0.08

0.40

0.32

0.17

1.99

1.60

0.21

0.57

0.14

(a) WHC sample number.

(b) PNL SUMMATM canister number.

(c) Obtained by mass-spectral interpretation and comparison with the EPA/NIST/WILEY Library.

(d) Semi-quantitative estimate calculated using concentration of the chlorobenzene- $d_{5}$ IS.

(e) Other structural isomers should be considered. 


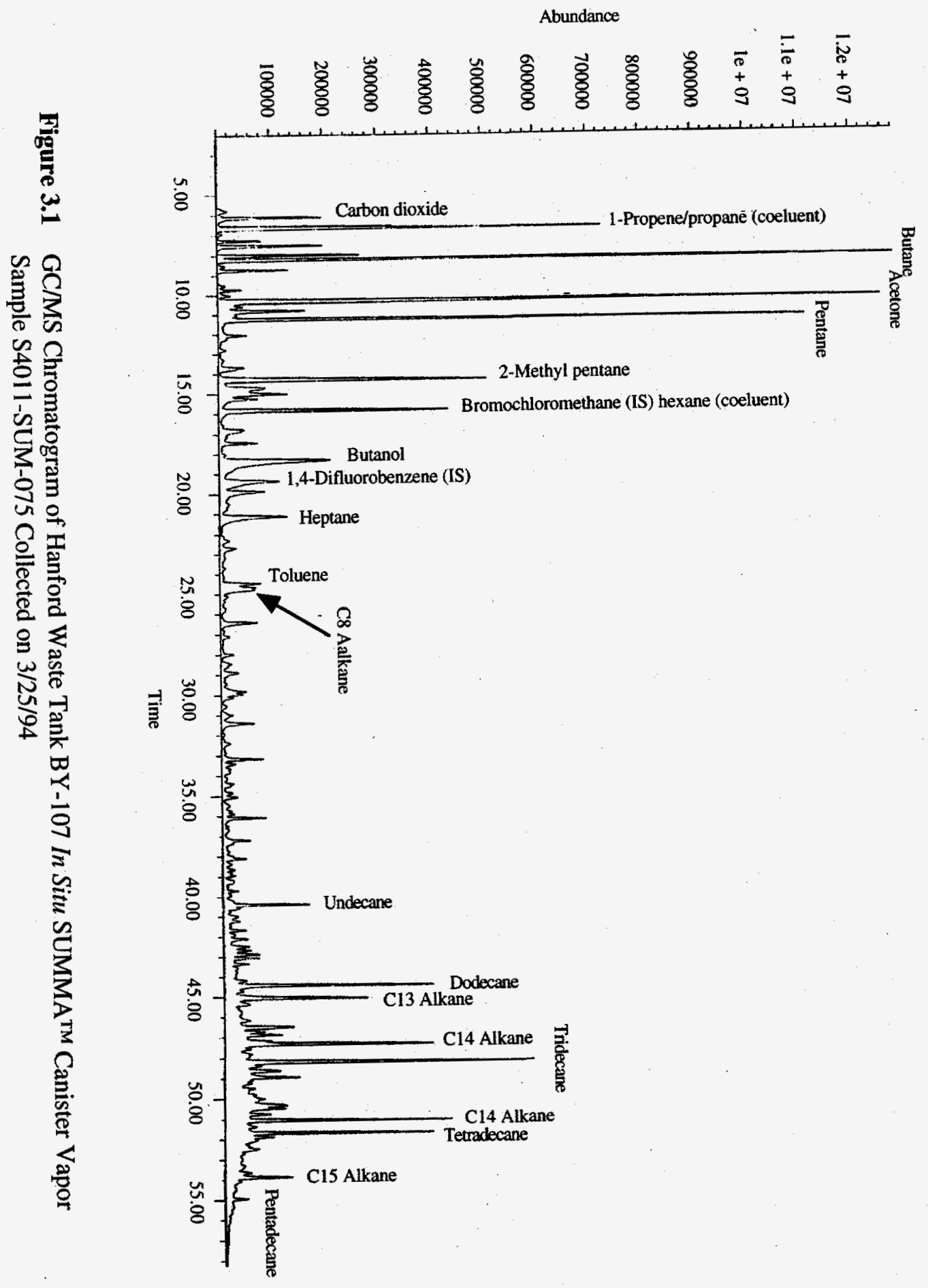




\section{Distribution}

No. of

Copies

\section{Offsite}

2 DOE Office of Scientific and Technical Information

\section{R. A. Jenkins}

Oak Ridge National Laboratory

P.O. Box 2008

Building 4500-5, MS 6120

Oak Ridge, Tennessee 37831-6120
No. of

Copies

Onsite

2 DOE Richland Operations Office

J. M. Clark, S7-54

T. Noble, S7-54

Corps of Engineers

T. W. Gardner-Clayson, A5-19

4 Westinghouse Hanford Company

H. Babad, R2-78

D. R. Bratzel, S7-21 (2)

J. E. Meacham, S7-15

27 Pacific Northwest Laboratory

S. C. Goheen, P8-08 (20)

J. L. Huckaby, K6-55

M. W. Ligotke, P7-59

Technical Report Files (5)

Dist. 1 